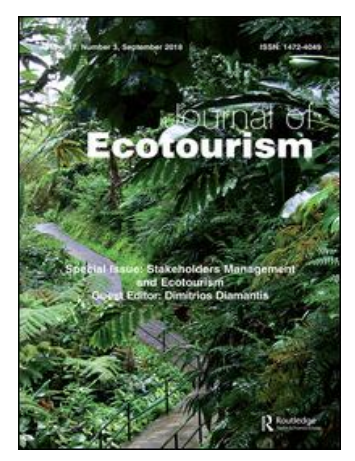

Journal of Ecotourism

\title{
Controllable drivers that influence tourists' satisfaction and revisit intention to Semenggoh Nature Reserve: the moderating impact of destination image
}

\author{
Wei-Chiang Chan, Wan Hashim Wan Ibrahim, May-Chiun Lo, Abang Azlan \\ Mohamad, T. Ramayah \& Chee-Hua Chin
}

To cite this article: Wei-Chiang Chan, Wan Hashim Wan Ibrahim, May-Chiun Lo, Abang Azlan Mohamad, T. Ramayah \& Chee-Hua Chin (2021): Controllable drivers that influence tourists' satisfaction and revisit intention to Semenggoh Nature Reserve: the moderating impact of destination image, Journal of Ecotourism, DOI: 10.1080/14724049.2021.1925288

To link to this article: https://doi.org/10.1080/14724049.2021.1925288

\section{曲 Published online: 19 May 2021.}

\section{Submit your article to this journal $\square$}

Џlll Article views: 89

Q View related articles ¿

View Crossmark data ¿ 


\title{
Controllable drivers that influence tourists' satisfaction and revisit intention to Semenggoh Nature Reserve: the moderating impact of destination image
}

\author{
Wei-Chiang Chan (10), Wan Hashim Wan Ibrahim ${ }^{\mathrm{b}}$, May-Chiun Lo ${ }^{\mathrm{a}}$, Abang \\ Azlan Mohamad ${ }^{a}$, T. Ramayah (1) ${ }^{c}$ and Chee-Hua Chin (iD) ${ }^{a}$

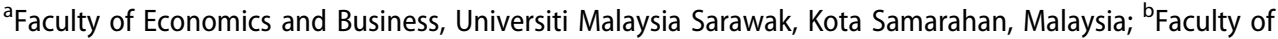 \\ Engineering, Universiti Malaysia Sarawak, Kota Samarahan, Malaysia; 'School of Management, Universiti \\ Sains Malaysia, Gelugor, Malaysia
}

\begin{abstract}
Ecotourism is a foremost promoted tourism product by the Malaysian government and significantly contributed to rural communities' income. The objective of this study was to explore the empirical evidence of the relationships among service quality, satisfaction, and revisit intention to an ecotourism site in Sarawak, namely, Semenggoh Nature Reserve by considering the moderating effect of the destination image. A total of 157 international and domestic tourists who visited the Semenggoh Nature Reserve took part voluntarily in this study. WarpPLS 6.0 software was used to perform the Partial Least Squares Structural Equation Modeling and hypotheses testing. The results revealed that service quality was found to significantly and positively impacting satisfaction, whereas satisfaction was found to drive revisit intentions. Additionally, the destination image was found to have a significant positive impact on tourist's satisfaction. The study further revealed that the destination image does not enhance the relationship between satisfaction and revisit intention.
\end{abstract}

\section{ARTICLE HISTORY}

Received 21 March 2020

Accepted 28 April 2021

\section{KEYWORDS}

Service quality; satisfaction; destination image; revisit intention tourists' perspectives; moderator; ecotourism

\section{Introduction}

Tourism is one of the fastest-growing industry which undergone tremendous growth for the last 50 years and it has become one of the major global economic sectors (Nilashi et al., 2019; Oviedo-García et al., 2016; Scott et al., 2019). In the Asia Pacific, Malaysia is one of the top 5 destination countries and the government has put much effort into boosting the tourism industry in order to diversify the economy (Al-Mulali et al., 2019). According to the Department of Statistics Malaysia Official Portal (2019), in the year 2018, the tourism industry contributed 15.2\% of Gross Value Added of Tourism Industries (GVATI) and 6.5\% of Tourism Direct Gross Domestic Product (TDGDP) to Malaysia Gross Domestic Product (GDP). Besides, the statistic released by Malaysia Tourism Promotion Board (2019) shows that, in the year 2018, Malaysia has received a total of 25.8 million international visitor arrival with a revenue of RM 84.1 billion 